Original Research Paper

\title{
Pelatihan Lesson Study Bagi Guru Fisika di SMAN 5 Mataram
}

\author{
Susilawati $^{1}$, Aris Doyan ${ }^{1}$, Kosim $^{1}$, Wahyudi ${ }^{1}$, Muhammad Zuhdi ${ }^{1}$ Musanni $^{2}$, Sri Rahmawati ${ }^{2}$ \\ ${ }^{I}$ Program studi pendidikan fisika, Fakultas Keguruan dan Ilmu Pendidikan, Universitas Mataram, Indonesia \\ ${ }^{2}$ SMA Megeri 5 Mataram
}

DOI: https://doi.org/10.29303/jpmpi.v3i2.506

Sitasi : Susilawati., Doyan, A., Kosim., Wahyudi., Zuhidi, M., Mussani., \& Rahmawati, S. (2020). Pelatihan Lesson

Study Bagi Guru Fisika di SMAN 5 Mataram. Jurnal Pengabdian Magister Pendidikan IPA, 3(2)

\section{Article history}

Received: 30 September 2020

Revised: 14 Oktober 2020

Accepted: 19 November 2020

*Corresponding Author:

Susilawati,

Program Studi

Pendidikan Fisika, Fakultas

Keguruan dan Ilmu Pendidikan,

Universitas Mataram,

Indonesia.

Email:

susilawatihambali@unram.ac.id

\begin{abstract}
Tujuan kegiatan pengabdian pada masyarakat ini adalah untuk meningkatkan kemampuan guru dalam melaksanakan proses pembelajaran fisika melalui kegiatan Lesson Study di SMAN 5 Mataram. Kegiatan ini dilakukan melalui tiga tahapan yaitu tahap persiapan, tahap pelaksanaan, dan tahap evaluasi. Secara umum kegiatan pelatihan ini berhasil dan tepat sasaran, karena guru-guru fisika SMAN 5 Mataram yang menjadi peserta merasa mendapatkan bekal tentang cara-cara pengembangan perangkat pembelajaran dan termotivasi untuk mencoba Lesson Study pada materi fisika lainnya. Selain itu, semua peserta didik sangat antuasias dan aktif dalam mengikuti pembelajaran. Berdasarkan hasil wawancara dengan peserta kegiatan pelatihan diperoleh data bahwa kegiatan tersebut sangat bermanfaat karena telah memberikan pengalaman kepada guru fisika di SMAN 5 Mataram terutama dalam mengembangkan perangkat pembelajaran yang dapat mengaktifkan peserta didik dalam pembelajaran. Peserta sangat berharap kegiatan pembinaan tersebut dapat dilaksanakan di waktu yang lain.
\end{abstract}

Keywords: Pembelajaran Fisika, Lesson Study.

\section{Pendahuluan}

$\mathrm{B}$ anyak faktor yang menyebabkan peserta didik tidak menyenangi pelajaran fisika, dan salah satunya adalah cara mengajar guru yang belum sesuai. Rendahnya hasil belajar disebabkan oleh beberapa faktor, yaitu peserta didik itu sendiri, guru, pendekatan pembelajaran, dan lingkungan belajar yang saling berhubungan satu sama lain (Darkasyi et al, 2014). Selain itu, prestasi belajar peserta didik yang rendah disebabkan oleh sejumlah faktor yang salah satunya adalah kompetensi guru yang tidak memadai (Tilaar et al, 2012).

Profesionalisme seorang guru dituntut dalam mengelola pembelajaran sehingga peserta didik lebih aktif belajar. Partisipasi peserta didik dapat ditingkatkan dengan cara pembelajaran harus berpusat pada peserta didik dan guru hanya sebagai fasilitator (Darling et al, 2009). Selain itu, guru harus memahami perannya sebagai fasilitator, serta mengenali ciri-ciri dan kecakapan yang mesti dimiliki oleh seorang fasilitator (Vera, 2012). Namun kenyataan yang terjadi di lapangan sangat berbeda, pembelajaran fisika dalam kelas masih berpusat pada guru, dimana peserta didik hanya dilatih untuk mengerjakan soal-soal dengan rumus yang tidak pernah diketahui dari mana asalnya, sehingga peserta didik menjadi bosan dan tidak tertarik dalam mengikuti proses pembelajaran. Hal inilah yang mengakibatkan hasil belajar peserta didik rendah (Wijaya, 2012). Hal ini tidak terkecuali pada pembelajaran fisika di SMAN 5 Mataram. 
Hasil observasi ditemukan bahwa proses pembelajaran fisika di sekolah tersebut masih bersifat student centered, dan peran guru dalam pengelolaan kelas masih kurang maksimal, sehingga berdampak negatif pada hasil belajar fisika peserta didik. Salah satu upaya untuk menyelesaikan masalah tersebut adalah dengan dilakukan pelatihan Lesson Study kepada guru fisika di SMAN 5 Mataram, sehingga kegiatan proses pembelajaran fisika di kelas terlaksana secara efektif dan efesien.

\section{Metode}

Menanggapi permasalahan yang mengakibatkan kurangnya kemampuan guru fisika dalam melaksanakan proses pembelajaran fisika yang efektif dan efesien, maka permasalahan ini dapat diselesaikan dengan cara memberikan pelatihan Lesson Study kepada guru. Beberapa tahapan yang akan dilalui dalam penyelesaian masalah ini yaitu tahap persiapan, tahap pelaksanaan, dan tahap evaluasi (Doyan et al, 2018; Susilawati et al, 2019). Secara sederhana tahapan ini direpresentasikan dalam Gambar 1.

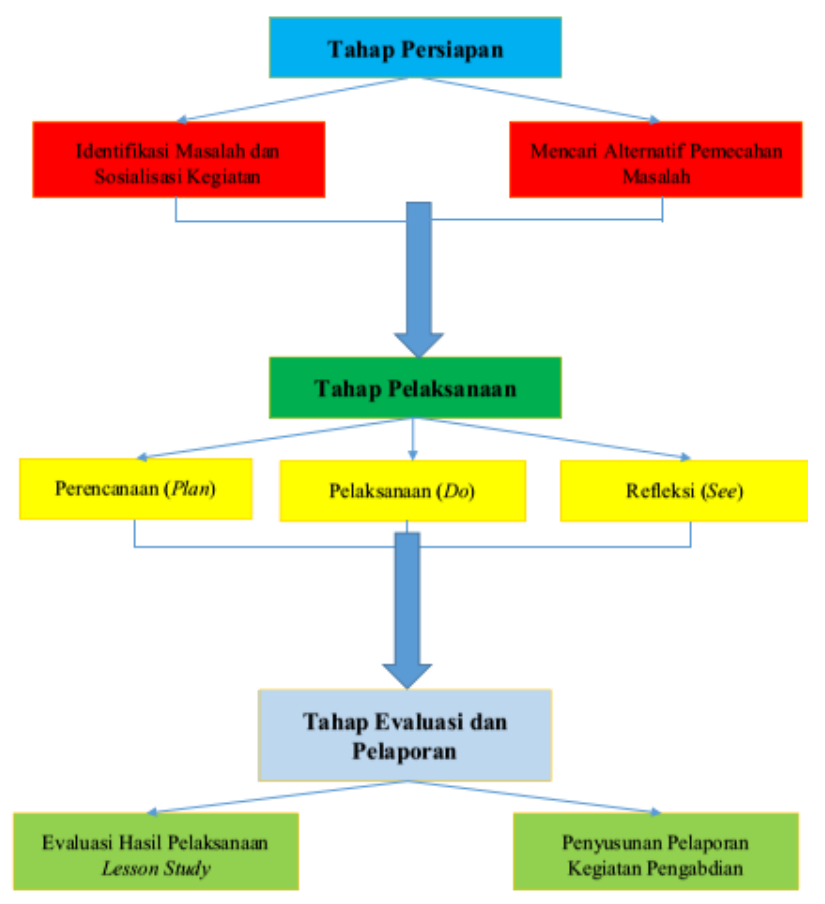

Gambar 1. Kerangka Pelaksanaan Kegiatan Pengabdian

Tahap persiapan dilakukan dalam bentuk observasi terhadap pelaksanaan pembelajaran fisika di sekolah SMAN 5 Mataram, guna untuk mengidentifikasi permasalahan yang dihadapi dalam pelaksanaan pembelajaran tersebut (Susilawati et al, 2019). Tahap pelaksanaan merupakan tindak lanjut untuk menyelesaikan permasalahan yang dialami oleh guru fisika di SMAN 5 Mataram, yaitu dengan dilaksanakan pelatihan langsung mengenai Lesson Study, sehingga dapat melaksanakan proses pembelajaran menggunakan Lesson Study dengan baik dan benar. Pada tahapan ini, guru diberikan pelatihan tentang Lesson Study. Setelah para guru memahami Lesson Study dengan baik dan benar, mereka melaksanakan proses pembelajaran fisika menggunakan Lesson Study. Tahap evaluasi dilaksanakan untuk mengidentifikasi kekurangan-kekurangan dari pelaksanaan pembimbingan dan pelatihan (Doyan et al, 2019; Susilawati et al, 2019). Tahap evaluasi hasil pelatihan dilakukan secara langsung dengan menilai pelaksanaan pembelajaran yang dilakukan oleh guru fisika di SMAN 5 Mataram menggunakan Lesson Study.

\section{Hasil dan Pembahasan}

Pelatihan Lesson Study bagi guru fisika telah dilaksanakan di SMAN 5 Mataram. Pelatihan Lesson Study meliputi tahapan-tahapan yaitu: perencanaan (plan), pelaksanaan $(d o)$, dan refleksi (see) (Sahidu et al, 2018). Sasaran pelatihan Lesson Study adalah semua guru fisika di SMAN 5 Mataram. Pelatihan tersebut berlangsung selama enam bulan dimulai dari tahap persiapan, pelaksannaan dan terakhir evaluasi (Doyan et al, 2018; Susilawati et al, 2019).

Tahap plan dilaksanakan pada tanggal 9 Oktober 2020 secara ofline di SMAN 5 Mataram. Tahap ini dihadiri oleh tiga orang guru fisika dan dua orang dosen fisika. Hasil plan ini adalah untuk kegiatan do, materi yang dibahas adalah induksi magnetik pada kelas dua belas IPA yang akan dilaksanakan pada pertemuan berikutnya. Tahap plan ditunjukan pada Gambar 2.

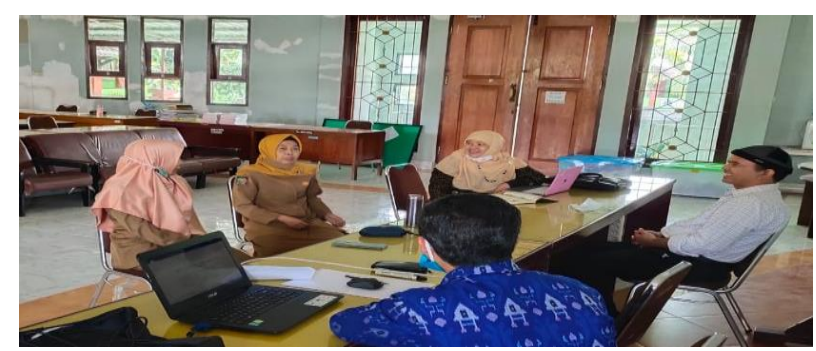

Gambar 2. Kegiatan plan oleh guru fisika SMAN 5 Mataram dan tim pengabdian 
Tahap do dilaksanakan pada tanggal 23 Oktober 2020 secara daring melalui zoom meeting. Tahap ini dihadiri oleh dua orang guru fisika, lima orang dosen fisika, dan dua puluh lima orang peserta didik kelas dua belas IPA. Pada tahap ini, seorang guru bertugas sebagai guru model, sedangkan guru yang lain dan tim pengabdian mengamati kegiatan pembelajaran yang sedang berlangsung untuk diberikan penilaian saat refleksi. Adapun materi fisika yang disampaikan adalah induksi magnetik (Gambar 3). Pembelajaran dilakukan melalui kegiatan praktikum menggunakan media virtual PhET.

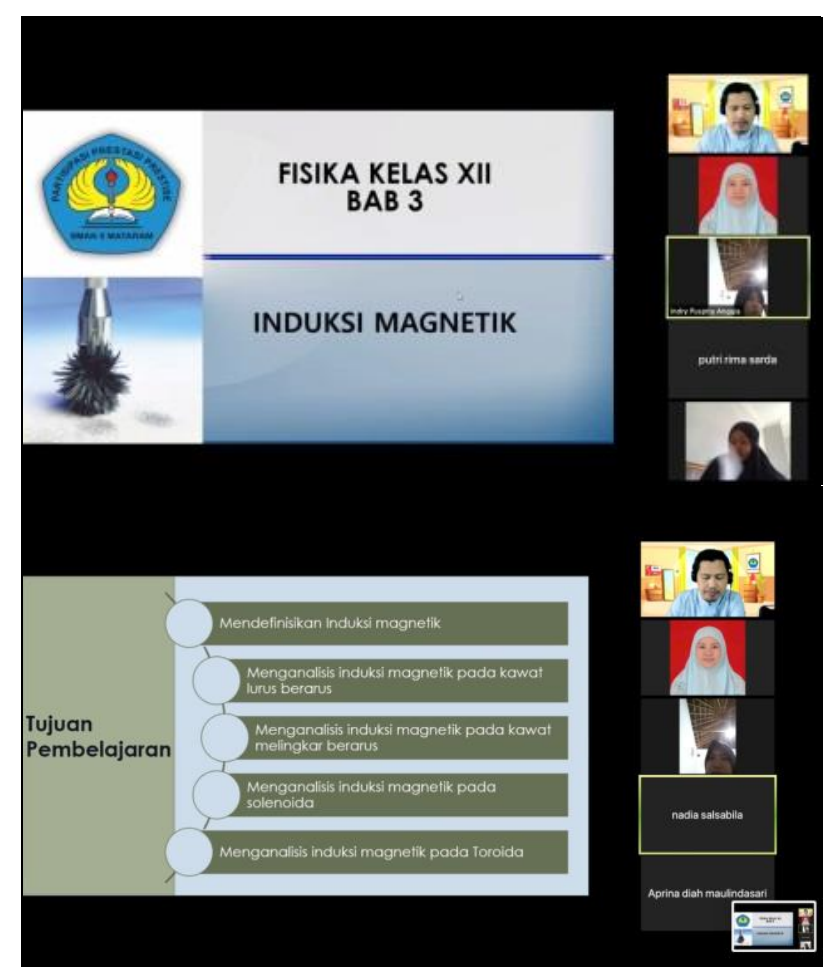

Gambar 3. Kegiatan penyampaian materi induksi magnetik oleh guru model

Pada proses pembelajaran, banyak peserta didik bertanya dan menjawab semua pertanyaan yang diberikan oleh guru. Selain itu, banyak terjadi interaksi antara peserta didik satu dengan peserta didik yang lainnya, serta terjadi banyak interaksi antara peserta didik dengan guru. Hal ini menunjukan bahwa dalam kegiatan pembelajaran tersebut semua peserta didik sangat antuasias dan aktif dalam mengikuti pembelajaran. Tahap do ditunjukan pada Gambar 4.

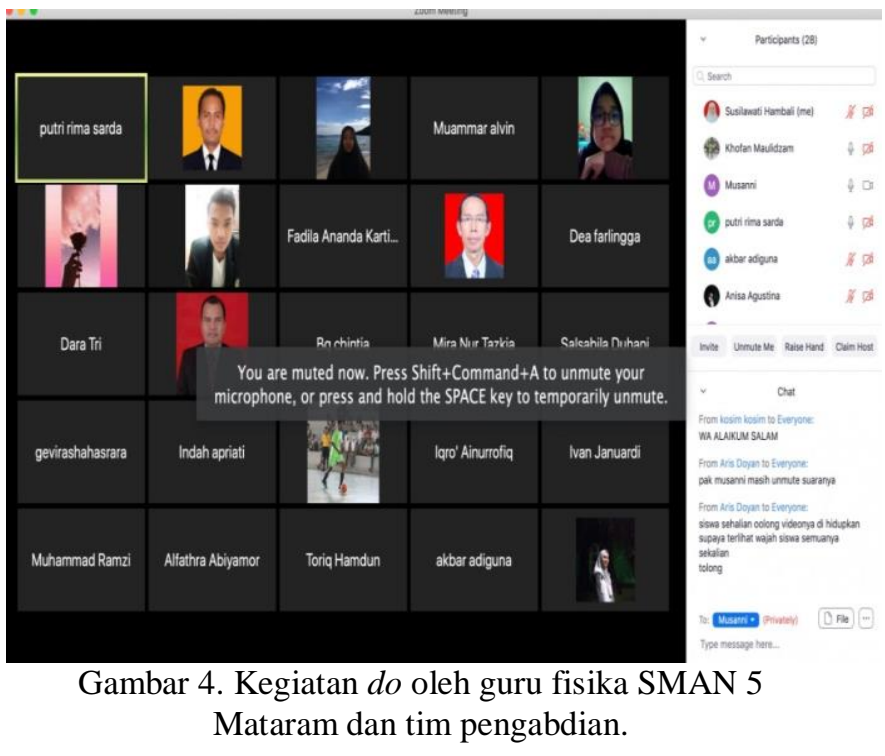

Tahap see dilaksanakan pada tanggal 23 Oktober 2020 secara daring melalui zoom meeting. Pada tahap ini, observer (guru dan tim pengabdian) memberikan penilaian dan tanggapan terkait dengan proses pembelajaran yang telah dilakukan oleh guru model. Hasil see dari observer diantaranya adalah secara keseluruhan proses pembelajaran berjalan lancar, semua sekenario yang telah direncanakan terlaksana dalam pembelajaran tersebut, tujuan pembelajaran tercapai semua, kegiatan pembelajaran cukup menarik dan sempurna, serta dapat diterapakan pada mata pembelajaran yang lain. Tahap see ditunjukan pada Gambar 5.

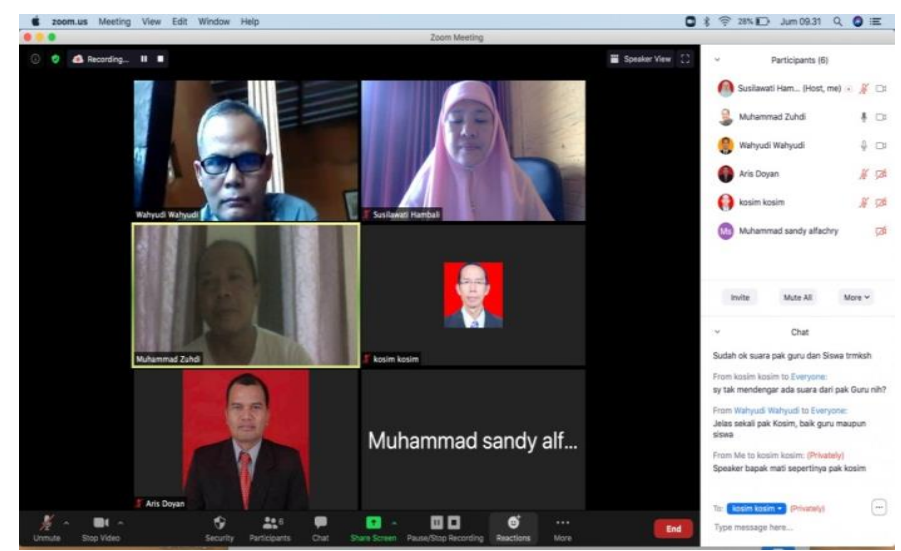

Gambar 5. Kegiatan see oleh guru fisika SMAN 5 Mataram dan tim pengabdian.

Secara keseluruhan kegiatan terlaksana dengan cukup sempurna, karena saat kegiatan plan, do dan see dapat dihadiri oleh semua guru yang telah sepakat untuk melaksanakan kegiatan 
tersebut. Hasil wawancara menunjukan bahwa guru model dan guru yang terlibat dalam kegiatan Lesson Study merasa senang sudah memperoleh pengalaman yang sangat berharga dengan adanya kegiatan tersebut. Adapun pengalaman yang dimaksud yaitu guru model dan guru yang terlibat dalam kegiatan Lesson Study dapat merancang perangkat pembelajaran yang dapat meningkatkan keaktifan peserta didik saat pembelajaran, melaksanakan pembelajaran yang sesuai dengan skenario pembelajaran yang telah disusun; guru model dan guru yang terlibat dalam kegiatan Lesson Study serta tim pengabdian dapat menjalin hubungan kerja yang baik. Hubungan baik ini layak untuk dilanjutkan agar kolegalitas antar guru meningkat dan pemenuhan hak belajar peserta didik SMAN 5 Mataram terpenuhi.

\section{Kesimpulan}

Kegiatan pengabdian kepada masyarakat berupa pelatihan Lesson Study bagi guru fisika di SMAN 5 Mataram ini sangat bermanfaat bagi guru karena dapat menambah wawasan tentang Lesson Study. Selain itu, pelatihan ini dapat menambah wawasan guru tentang bagaimana merancang perangkat pembelajaran yang dapat meningkatkan keaktifan peserta didik saat pembelajaran. Secara umum kegiatan pelatihan ini berhasil dan tepat sasaran, karena guru-guru fisika SMAN 5 yang menjadi peserta merasa mendapatkan bekal caracara pengembangan perangkat pembelajaran dan termotivasi untuk mencoba Lesson Study pada materi fisika lainnya.

\section{Saran}

Kegiatan pelatihan Lesson Study bagi guru fisika ini sudah berjalan dengan lancar. Kegiatan ini perlu dilanjutkan agar wawasan guru tentang pembelajaran dengan Lesson Study bertanbah sehingga tercipta pembelajaran aktif, efektif dan menyenangkan bagi peserta didik.

\section{Ucapan Terima Kasih}

Tim pengabdian mengucapkan terima kasih kepada kementerian riset, teknologi, dan pendidikan tinggi yang telah membiayai kegiatan pengabdian ini.

\section{Daftar Pustaka}

Allen, D., Donham, R. dan Tanner, K. 2004. Approaches to Biology Teaching and Learning: Lesson study-Building Communities of Learning Among Educators. Cell Biology Education. (3), 001-007.

Darkasyi, M., Johar, R. dan Ahmad, A. 2014. Peningkatan Kemampuan Komunikasi Matematis dan Motivasi Peserta didik dengan Pembelajaran Pendekatan Quantum Learning pada Peserta didik SMP Negeri 5 Lhokseumawe. Jurnal Didaktik Matematika,(1), 1, 21-34.

Darling, L., Hammond dan Richardson, N. 2009. Research Review/Teacher Learning: What Matters? on How Teachers Learn, (66),5, 46 $-53$.

Doyan, A., Susilawati, Soeprianto, H. dan Bahri, S. 2018. Pelatihan Olimpiade MIPA Bagi Guru dan Peserta Didik SMA Kesuma Mataram. Jurnal Pengabdian Magister Pendidikan, (1), $1,20-23$.

Doyan, A, Susilawati, Bahri, S., Muhlis, dan Artayasa, I. P. (2019). Pelatihan Pemantapan Konsep Materi Fisika dan Pengukuran Bagi Guru IPA di SMPN 9 Mataram. Jurnal Pengabdian Magister Pendidikan IPA (JPMPI). (2), 1, 24-27.

Isoda, M. 2007. Japanese Lesson Study in Mathematics, Its impact Diversity and Potential for Education Development. Singapore:World Scientific Publishing C. Pte. Ptd.

Murata, A., Hart, L. dan Alston, A. 2011. Lesson Study Research and Practice in Mathematics Education. Newyork: Springer.

Perry, R., Lewis, C., Friedkin, S. dan Baker, E. 2009. Teachers' Knowledge Development During Lesson Study: Impact of ToolkitSupported Lesson Study on Teachers' Knowledge of Mathematics for Teaching. Paper presented at AERA. March 24, 2009, San Diego.

Sahidu, H., Gunawan, Kosim dan Rahayu, S. 2018. Penyuluhan Tentang Lesson Study (LS) untuk Meningkatkan Kompetensi Pedagogik Guru-Guru di MAN 2 Mataram. Jurnal Pendidikan dan Pengabdian Masyarakat. (1), 1, 19-26. 
Stepanek, J. 2001. A New View of Professional Development. Northwest Teacher. Spring, (2), 2, 2-5.

Stepanek, J. 2003. Researchers in Every Classroom. Northwest Teacher. Spring. (4), 3, 2-5.

Susilawati, Doyan, A., Taufik, M. dan Zuhdi, M. 2019. Pengayaan Materi Olimpiade Fisika dan Pelatihan Penyelesaian Soal-Soal Olimpiade Fisika Bagi Guru dan Siswa di SMP Islam Terpadu Putra Mataram. Jurnal Pengabdian Magister Pendidikan IPA (JPMPI), (2), 1, 34-36.

Susilawati, Doyan, A. dan Taufik, M. (2019). Pengayaan Materi Olimpiade Fisika dan Pelatihan Penyelesaian Soal-Soal Olimpiade Fisika Bagi Guru dan Siswa di Sekolah Mitra. Jurnal Pengabdian Magister Pendidikan IPA (JPMPI). (2), 1, 1-5.

Tilaar, R. A. H., Sutjipto dan Handoyo, S. S. 2012. Improving the quality of education in remote areas: The case of the sra program in the elementary schools of Kabupaten Lembata, NTT on NEWSLETTER No. 33 Dec/2012.

Vera, A. 2012. Metode Mengajar Anak di Luar Kelas. Jogjakarta: Diva Press.

Wijaya, A. 2012. Pendidikan Matematika Realistik Suatu Alternatif Pendekatan Pembelajaran Matematika. Yogyakarta: Graha Ilmu. 